\title{
Samuel Beckett's Waiting for Godot Therapeutic Perspective
}

\author{
Ghassan Awad Ibrahim
}

Department of English, Al-Turath University College, Baghdad, Iraq

Received: 07 Nov 2021; Received in revised form: 11 Dec 2021; Accepted: 20 Dec 2021; Available online: 28 Dec 2021

(C)2021 The Author(s). Published by Infogain Publication. This is an open access article under the CC BY license

(https://creativecommons.org/licenses/by/4.0/).

\begin{abstract}
This research aims to tackle the problems and difficulties that face people after wars and their horrific consequences. As a result, people after the end of any wars or catastrophes are made to suffer the trauma of the hardship of life and the social disintegration of their communities not to mention the loss of their lovers and all forms of destruction. Thus, there will be suggestions of psychological recovery throughout this research which may improve the psyches of those who have traumatic experiences.

The research also aims at acquainting the reader with Samuel Beckett's treatment in his masterpiece Waiting for Godot of the devastating World War II (1939-1945) and its negative impacts on people as he exerts much efforts to show the horrific consequences of that recent war as if he addresses all people worldwide and warns them at the same time of the risks of evil, wars in particular, when he gives succinct descriptions of people suffering from the harshness of lifein the fifties of the last century in his drama which may stem from his moral responsibility as a playwright aware of the dangers of wars that usually claim uncountable numbers of death toll and leave the world destructive and most of its survived people traumatized, trying intensely to survive in a world that deprives them of their simplest rights of living.
\end{abstract}

Keywords-Horrific consequences, Trauma, recovery, and Survival.

\section{INTRODUCTION}

Waiting for Godot, written by the Irish playwright Samuel Beckett (1906-1989) between "Oct. 9, 1948 and Jan. 29, 1949," (C.J and S.E. 2006, p. 620)and acted at the Theatre de Babylone in Paris in 1953 is a "tragicomedy in two acts."(Ibid, p. 127) Beckett, the most famous absurdist playwright, is also well-known for his plays such as Endgame (1957), Act Without Words I (1957), Kapp's Last Tape (1958), Act Without Words II (1960)in which all of them belong to the Theatre of The Absurd that can be defined as a " term applied to a group of dramatists in the 1950s and 60s such as Samuel Beckett, Jean Genet, Eugene Ionesco, Edward Albee, Arthur Adamov, and Harold Pinter. Their attitude is based upon the belief that the condition of man in this world is absurd, ridiculous, and irrational. The term (absurd) was coined by Martin Esslin in his study of contemporary playwrights, The Theatre of the Absurd (1961)." (Cuddon, 1980: p.692)The absurdist dramatists have become extensively known since
World War II (1939-1945) that left Europe, including England, devastated and wrecked in which "The experience of England during the Second World War (1939-1945) was far more catastrophic than that during the First World War." (Moody, Lovett, 1964: pp. 421422)when it left millions of people homeless and refugees along with the breakdown down of the European economy, leaving English people, in particular, in very miserable conditions because "By the end of the war in September 1945, England had suffered not only the loss of hundreds of thousands of young men but the devastation of wide areas in London and elsewhere and staggering blows to its economic system and its financial life and character."(Ibid, p. 422)Furthermore, one of the many losses of the devastation of WWII was the "illusion of manly honour and glory in battle. Under conditions of unremitting exposure to the horros of trench warfare, men began to breakdown in shocking numbers. Confined and rendered helpless, subjected to constant threat of annihilation, and 
forced to witness the mutilation and death of their comrades without any hope of reprieve." (Herman, 2015: p. 20)Moreover, the previous fierce war caused catastrophic social disintegration in the fabric of the European communities which was deeply damaged by it. Besides, it left plenty of widows, orphans and destitute people homeless and without breadwinners not to mention unemployment, prostitutions, chaotic murdering, thefts and all images of evil that posed serious problems for the survived people to suffer not only physically but also psychologically, prompting most of them to feel lost and lonely in their countries.

Therefore, life of people after the previous is characterized by futility and monotony and people have neither goal nor motivation in their life which are necessary to achieve genuine stature as they are depicted in the play by the two protagonists (Vladimir and Estragon) who represent European people, including young men, after war who are seen to spend their time waiting for someone who is represented by Godot to come and save them from their miserable conditions or something to happen so that they can improve their situation. In the play, Vladimir and Estragon isolate themselves from other people to live in a forsaken, open, and arid area as "Nothing happens, nobody comes, nobody goes, it's awful," (Beckett, 1978: p. 41)engaging in circular, meaningless conversations and their life is seen as absurd since it is without meaning, depressed and funny at the same timeas "Nothing is funnier than unhappiness ... it's the most comical thing in the world," (Beckett: 1958, pp. 18-19)as Beckett highlights the tension of life and the meaninglessness of it in his play to show the absurdity of life and to expresses a nihilistic view of human meaningless existence. (Essif, 2001: pp. 19)Hence, the theatre of the absurd seems to be pessimistic and comic simultaneously, having satire and parody. It is described by the English professor Jean E. Kennard as it "is often pessimistic in vision, comic in tone, and contains strong elements of satire or parody." (Kennard, 1975: p. 1)Apparently, Beckett when writing the play was aware of the plights of the previous war and its horrific consequences, depicting them in a skillful literary style as if he separated the wheat from the chaff to reveal the truth about what really happened to common people after that fierce war to raise the idea of human dignity especially when that war left most of the European people traumatized, humiliated, incoherent, and lost in their wartorn countries" In this conflict not only the military forces but the civilian population were intimately involved; it was not merely armed forces that paid heavily in what Prime Minister Winston Churchill tersely described as(blood, sweet, and tears)."(Moody, Lovett, 1964: p. 422)

\section{DISCUSSION AND ANALYSIS}

Waiting for Godotshows the bitter lives of the two tramps Vladimir and Estragon who seem that they escape from their original residence where war is underway to live at a forsaken area for safety. They distract themselves in trivial actions as they talk and keep asking each other about this and that, eat faddish food such as a carrot or turnip, or radish which all they have, exchange conversations and obscenities, to pass time and to get rid of thinking because they are so psychologically exhausted that even the process of thinking hurts them "We're in no danger of ever thinking anymore," (Beckett, 1978: p. 64) while waiting for Godot since they think that the latter is their "saviour" and the lonely hope to come one day and save them from their squalid conditions as they live in a desert where no plant can grow and no animal can be bred there. In fact, Godot is the creation of their imagination as they do not know him or even having an appointment with him. When they are asked by Pozzo, another character in the play, who suddenly along with his carrier Lucky interrupt the process of their waiting, about the identity of Godot, Estragon replies "... we hardly know him." (Ibid, p. 23)In fact, the two tramps are so frustrated that they are unable to achieve anything that enhance their life as "Nothing to be done," (Ibid, p. 11) about it, therefore, they attempt to commit a suicide twice but they fail. So, even death for them is unattainable as they have no means to fulfill that. Their first attempt of killing themselves to get rid of their miserable life was by hanging themselves from the bare and lonely tree but they failed as they have no rope that is why, they decide to come back the next day "Then we can bring a good bit of rope." (Ibid, p 94) The second attempt when they decided illogically to throw themselves from the Eiffl tower but even this attempt did not achieve success when Vladimir justified that "Now it's too late. They wouldn't even let us up." (Ibid, p. 10)

Obviously, Vladimir and Estragon oblige themselves to keep waiting for Godot because they seem indolent as they do not do anything to improve their situation but submitting themselves to the idleness which is a very bad thing for human nature and to the process of waiting which is by "itself a contradictory combination of doing nothing and doing something." (Hayman, 1980: p. 4) Besides, they repeatedly claim that "Nothing to be done," (Beckett, 1978: p. 11)while they at least can move and probably they may find a better place to live in but "They don't move." (Ibid, p. 54)However, waiting boundlessly for someone who would never come generates suffering and makes life tedious and boring and it is only resulted in loneliness, bitterness, and ambiguity. It is a matter of fact that everyone in this mortal world suffers not only Vladimir who physically suffers when he faces a difficulty in his 
urination while Estragon is mentally ill since he imagines that whenever and wherever people meet him they beat him for reasons he knows nothing about Estragon thinks that he is the only one who suffers, confirming that people "certainly they beat me,"(Ibid, p. 9) prompting Vladimir to tell him angrily that "No one ever suffers but you, I don't count. I'd like to hear what you'd say if you had what I have." (Ibid, p.10)Lucky who is another character in the play also suffers when he carries all the time the heavy stuff of his master Pozzo who drives him by a whip and ties his neck by a rope as if he is an animal in the early beginning of the play when they enter the stage "Pozzo drives Lucky by means of a rope passed round his neck, so that Lucky is the first to appear before Pozzo appears. Lucky carries a heavy bag, a folding stool, a picnic basket and a greatcoat. Pozzo a whip." (Ibid, p. 21) Pozzo who owns everything such as food, a bottle of wine, a folding stool, a pipe and tobacco, as well as the land where Vladimir and Estragon are waiting for Godot, thinking arrogantly that he differs from other characters who are starved and are created to suffer as he will never suffer, asking "Do I look like a man that can be made to suffer?" (Ibid, p.34) but finally he suffers when he goes blind.

As a social reformer, Beckett has successfully depicted in Act 1 a dead tree in that desolate area where Vladimir and Estragon wait endlessly for Godot as it is a symbol of death and it also may represent the breakdown of the European economy as it is bare, dry, fruitless, leafless and thin and at the same time it looks like the cross on which Jesus Christ was crucified as another sign of death. But in Act II the tree signifies hope and a new life when it sprouts "four or five leaves." (Ibid, p. 57) Besides, he shows that all the characters are common people except Pozzo who appears to be a capitalist as he owns everything, including Lucky, who obeys his orders obediently and respectfully. He serves him for a long time as a "dog-like devotion," (Kalb, 1989: p. 175)and expects ingratitude from Pozzo who doesn't only bring him to a fair where he can get a good price for him through selling him because he is no longer useful due to his old age but he also thinks to kill him "... But instead of driving him away as I might have done, I mean instead of simply kicking him out on his arse, in the goodness of my heart I am bringing him to the fair, where I hope to get a good price for him. The truth is you can't drive such creatures away. The best thing would be to kill them." (Beckett, 1978: p. 32)Vladimir who is watching astonishingly nearby pities Lucky and therefore, heboldly criticizes Pozzo for his rudeness towards the aged man, telling him surprisingly "After having sucked all the good out of him, you chuck him away like a ... like a banana skin."(Ibid, p.34) The rude behaviour of Pozzo against Lucky is similar to the actions of the capitalist companies when they exploit their workers when they are young, and when they become old they discharge them without any pension. In his play, A Death of a Salesman (1949), the American playwright Arthur Miller deals with "the problems of an ordinary man in a conscienceless, capitalistic social system."(Abbotson, 2005: p. 60)According to Collins Cobuild Dictionary, capitalism which appears in the fifties of the last century and more specifically after the WWII in America is defined as an "economic and political system in which property, business, and industry are owned by private individuals and not by the state," exploiting and abusing common people such as the character Willy Loman in the aforementioned play to attain "Corporate money, government support, and grants reward those who stay on script, who do not challenge the cruel structure of imperialism, the permanent war economy, and unfettered capitalism."(Malpede, 2011, vii) In the play, Loman is discharged without even a reward from his private company after serving it faithfully for more than thirty years. Loman is immediately discharged after he just asks his boss at his work to transform him to another branch of the company to be near his family for his old age. The American playwright Karen Malpede explains that the human rights abuses of the capitalist companies against their aged workers represent "the failure of a way of life."(Ibid, p.66)The quick and the unexpected discharging of Willy which deprives him of the simplest rights of living, causing him to be so traumatized, depressed and hopeless that he commits a suicide to get rid of his suffering.

Hence, the previous war does not only cause destruction of the infrastructures of the warring countries but it also paves the way to new economic systems such as capitalism to appear. Furthermore, war traumatizes some people and causes them psychological damage, turning their life into humiliation as they lose self-control such as Lucky who is humiliated, serving Pozzo as if he is his slave and whom is pitied by Vladimir who blames Pozzo decisively for his immoral treatment to him, saying "To treat a man... like that...I think that...no...a human being...no...it's a scandal!" (Ibid, p. 27) or at least to someone without dignity just like Estragon who cannot forbid himself from asking Pozzo humiliatingly about the bones which are left by the latter after finishing his meal, saying "Er...you've finished with the ...er...you don't need the...bones, sir? (Ibid, p.26)After getting permission to have the bones, Estragon shamelessly picks them up and begins to suck them. However, Lucky is still loyal to Pozzo even when the latter goes mysteriously blind which gives the sense of connection that they cannot be inseparable just like in the 
case of Vladimir and Estragon who are also inseparable and "tied to Godot." (Mercier, 1990: p. 53)

The traumatic experience due to the previous war which may cause psychological damage for some people like the characters Estragon and Lucky may be "drawn off by abreaction or by thought-work." (Freud, Breuer, 1952: p.81)But unfortunately, the tramps do not do anything to improve their situation as they claim repeatedly "Nothing to be done," (Beckett, 1974: p. 11) about boosting the condition of their miserable life as they are not aware of the dangers to their future which seems uncertain. In fact, they determine their awareness of salvation between hope and the non-arrival of Godot who is for them considered their saviour. For Bessel Van Der Kolk, an American psychiatrist, who supports Freud's way of recovery, confirming that "the talking cure, an offshoot of Freudian psychoanalysis, was still the primary treatment for mental illness," (Kolk, 2014: p. 22)while Judith Lewis Herman, the American psychiatrist, assures that the vital treatment of the traumatized patients lies in "reconstructing the trauma story, and restoring the connection between survivors and their community." (Herman, 2015: p. 3)The American Journalist and critic Chris Hedges (born 1956) writes in his foreword in Karen Malpede's Acts of War: Iraq and Afghanistan in Seven Plays (2011) a poignant criticism which may be considered an antiwar message against high ranking politicians and religious people of his country who agree with them to wage wars, saying about "those politicians who speak of war but do not know its reality, those powerful statesmen - the Henry Kissingers, Robert McNamaras, Donald Rumsfelds, the Dick Cheneys, the Barak Obamas - those who treat war as part of the great game of nations, are as amoral as the religious stooges who assist them." (Malpede, 2011: viii-ix)

Although Beckett has magnificently depicted symbols such as the tree or even the exhausted tramps to show the real depressing image of life after WWII, he does not give solutions as the tramps do not make anything to recover their miserable situation but they submit themselves illogically and helplessly to the idea of waiting for Godot who has never appeared in the play. Therefore, it seems clearly that the tramps suffer mentally especially Estragon who imagines that people come to beat him, prompting Vladimir to defend him by telling him that he "wouldn't have let them beat [him]." (Beckett, 1978: p. 59) The psychiatrist Kolk submits a significant way of curing mental disorder patients called self-awareness in which the patients should be the doctors of themselves as they should be aware of their personalities:

At the core of recovery is selfawareness. The most important phrases in trauma therapy are

'Notice that' and 'What happens next?' Traumatized people live with seemingly unbearable sensations: They feel heartbroken and suffer from intolerable sensations in the pit of their stomach or tightness in their chest. Yet avoiding feeling these sensations in our bodies increases our vulnerability to being overwhelmed by them.

(Kolk, 2014: p 210)

As long as the self-awareness way of recovery is concerned, Klok pinpoints that "the challenge of recovery is to reestablish ownership of your body and your mind of yourself. This means feeling free to know what you know and to feel what you feel without becoming overwhelmed, enraged, ashamed, or collapsed." (Kolk, 2014: p. 205)Similarly, Herman suggests that those who survive wars with mental disorders "must invent their own methods, drawing on their individual strengths and the supportive relationships naturally available to them in their own communities." (Herman, 2015: p. 240) The American professor Cathy Caruth who is well-known for her book Trauma Explorations in Memory (1995) remarks "To cure oneself - whether by drugs or the telling of one's story or both - seems to many survivors to imply the giving-up of an important reality, or the dilution of a special truth into the reassuring terms of therapy." (Caruth, 1995: vii)

\section{CONCLUSION}

It is true that Beckett's play shows a pessimistic view of life but this is the reality of people and things after the WWII in which the play as a whole forms a moral lesson to people to beware of the dangers of war. Moreover, the play is a message to people not to be idle like the protagonists in the play Vladimir and Estragon who try only to put an end to their life so that they can get rid of their suffering and when they fail to do that their only effort to enhance their depressed situation is the process of waiting for someone whom they do not know or even they have no appointment with him. They should at least have the courage to move so that they can leave the desolate area where they live to find a new one which may provide them with new opportunities of living. Besides, they have to involve themselves with groups so that they can get comfort and communication as well to exchange and share their thoughts and ideas with them to make their life better. 


\section{REFERENCES}

[1] Abbotson, Susan C. W (2005) Masterpieces of 20th-Century American Drama. London,Greenwood Press, Westport, Connecticut.

[2] Beckett, Samuel (1958) Endgame: a play in one act, followed by Act without words, a mime for one player. Grove Press.

[3] Beckett, Samuel (1978) Waiting for Godot, London: Faber And Faber Limited. All subsequent textual quotations and references which will appear in my paper within parentheses in the text are based on this reference book. All spellings are kept as in the original.

[4] Caruth, Cathy (1995)Trauma Explorations in Memory. Baltimore and London. The Johns Hopkins University Press.

[5] C. J. Ackerley, and S. E. Gontarski, (Eds.) (2006) The Faber Companion to Samuel Beckett, London: Faber and Faber.

[6] Cuddon, J.A. (1980)A Dictionary of Literary Terms, United States of America, Doubleday \& Company, Inc.

[7] Essif, Les. (2001) Empty figure on an empty stage: the theatre of Samuel Beckett and his generation. Indiana University Press.

[8] Freud, Sigmund and Breuer, Joseph (1952)Studies in Hysteria. London. Imago Publishing Co., Ltd.

[9] Hayman, Ronald, (1980) Samuel Beckett, London: Heinemann.

[10] Herman, Judith (2015) Trauma and Recovery; The Aftermath of Violence - From Domestic Abuse to Political Terror. New York, Basic Books, A member of the Perseus Group.

[11] Kalb, Jonathan (1989) Beckett in Performance, Cambridge: Cambridge University Press.

[12] Kennard, Jean E. Kennard (1975) The Theatre of the Absurd, New York: Harper\& Row, Publishers, Inc.

[13] Kolk, Bessel Van Der (2014):The Body Keeps The Score; Brain, Mind and Body in the Healing of Trauma.New York 10014 , penguin.com.

[14] Malpede, Karen (2011) et. al. Acts of War, Iraq and Afghanistan in Seven Plays.United States of America. Northwestern University Press.

[15] Mercier, Vivian (1990) Beckett, London: Souvenir Press.

[16] Moody William Vaughn, Lovett Robert Morss (1964) A History of English Literature, Eighth Edition By Fred B. Millett, New York, Charles Scribner's Sons. 